Nigerian Journal of Physiological Sciences 24 (2): 117 -120 @Physiological Society of Nigeria, 2009

Available online/abstracted at http://www.bioline.org.br/np; www.ajol.info/journals.njps; www.cas.org

\title{
SERUM PROTEIN AND ENZYME LEVELS IN RATS FOLLOWING ADMINISTRATION OF ETHANOLIC LEAF EXTRACT OF AGERATUM CONYZOIDES (GOAT WEED)
}

\author{
A. B. ANTAI, E. U. EYONG ${ }^{1}$, M.U. ETENG ${ }^{1}$, E. H. ITAM ${ }^{1}$, M. E. EKO ${ }^{2}$ and S.O. ITA ${ }^{3}$ \\ Departments of Physiology, Biochemistry ${ }^{1}$ and Botany ${ }^{2}$, University of Calabar, Nigeria. Department of \\ Physiology, University of Uyo, Uyo, Nigeria E-mail: eubana@yahoo.com,Tel: +2348055609962
}

\begin{abstract}
Summary: The potential hepatotoxic effects following oral administration of ethanolic leaf extract of Ageratum conyzoides (goat weed) was investigated in albino Wistar rats. Twenty eight (28) adult male Wistar rats were uniformly divided into four groups of seven rats each. Group 1 served as control while groups 2, 3 and 4 were respectively gavaged with $200 \mathrm{mg} / \mathrm{kg}$ body weight, $400 \mathrm{mg} / \mathrm{kg}$ body weight and $600 \mathrm{mg} / \mathrm{kg}$ body weight of the extract daily for 21 days. At the end of treatments, animals were sacrificed, serum and liver tissues obtained for assay of total protein concentration and levels of ALT, AST and ALP. Results showed that treatment of rats with the respective doses of the extract did not significantly alter the serum and liver levels of total protein, ALT, AST and ALP in all test groups. This result suggests that ingestion of the extract may not be toxic at the doses investigated.
\end{abstract}

Keywords: Ageratum conyzoides, rats, toxicological effect.

\section{Introduction}

Ageratum conyzoides is a herbaceous plant used in traditional medicine in several countries of the world. The use of this herb as a bacteriocide, antidysentric and antibiotic has been reported for communities in Asia, Africa, India and South America (Almagboul, 1985; Ekundayo et al, 1988; Borthakar and Baruah, 1997).

In East Africa it is used as an astringent /haemostatic for dressing injuries by local farmers and its antibiotic, anti-inflammatory and analgesic properties have been verified (Durodola,1977). In some local communities in Nigeria, the plant leaves are used in the management of fever, pneumonia and rheumatism. Various parts of this plant contain many secondary metabolites (Kong et $a l, 2004)$ which are responsible for the medicinal and therapeutic effects reported of this plant. The ethanolic extract of the roots and aerial parts of A. conyzoides have been reported to exhibit gastroprotective activity via $\mathrm{Ca}^{2+}$ channel blocking and antiserotogenic properties (Achola and Munenge, 2004). Ita et al (2005) have reported the ability of the aqueous leaf extract of A. conyzoides to stimulate gastric acid secretion. In another study Ita et al (2007) have also reported the advantageous effect of the ethanolic leaf extract on haematological indices of rats. Given the traditional use of the plant in the management of various ailments, it becomes necessary to evaluate its toxicological potential in order caution or encourage its use in traditional medicine.

\section{Materials and Methods \\ Collection of Plant Material}

The whole plant was obtained from the staff village, University of Calabar, Calabar, Nigeria. Specimen of the leaves was authenticated by Dr. Micheal Eko of the Department of Botany, University of Calabar, Calabar. A voucher specimen (EU 2008) was deposited at the herbarium.

\section{Preparation of Leave Extract}

The leaves of $A$. conyzoides were rinsed with distilled water and dried under shade. The dried leaves were ground into powder with an electric blender. Four hundred grammes of the blended leaves sample was macerated in $700 \mathrm{ml}$ $80 \%$ ethanol, agitated for 10 minutes with an electric blender and left overnight in a refrigerator at $4^{\circ} \mathrm{C}$. The mixture was filtered with a cheese cloth and the filtrate obtained concentrated under reduced pressure using a rotary evaporator (at $37^{\circ} \mathrm{C}$ ) to about $10 \%$ of its original volume. The concentrate was then allowed in a water bath at $37^{\circ} \mathrm{C}$ for complete evaporation to dryness yielding $38.94 \mathrm{~g}(9.7 \%)$ of the extract.

Animals

Male albino Wistar rats weighing 220-240g were obtained from the disease free stock of the animal house, Department of Biochemistry, University of Calabar and use for the study. The 
A. B. ANTAI et al

animals were housed in plastic cages with plastic bottom and wire mesh top (North kent Co. Ltd, England), under standard conditions of temperature $\left(28 \pm 2^{\circ} \mathrm{C}\right)$ and relative humidity $(46 \pm 5 \%)$ with a $12 \mathrm{~h}$ light- dark cycle and adequate ventilation. The animals were allowed normal rat chow(Guinea Feed Nig. Ltd. Benin) and water ad libitum throughout the study.

\section{Grouping and Treatment of animals}

The animals were assigned into four groups of seven rats each. Group 1 animals were control animals which received placebo treatment, while group 2,3 and 4 were respectively treated with $200 \mathrm{mg} / \mathrm{kg}$ body weight, $400 \mathrm{mg} / \mathrm{kg}$ body weight and $600 \mathrm{mg} / \mathrm{kg}$ body weight of the extract. The extract was administered to the rats daily by oral gavage for a period of 21 days.

\section{Collection of Serum and Liver Samples}

Twenty four hours after the last administration, the animals were anaesthsized under chloroform and dissected. Blood was obtained via cardiac puncture into plain sample tubes and allowed to stand for 2 hours and thereafter centrifuged at $2000 \mathrm{~g}$ for 10 minutes to separate serum from the blood cells. The blood serum obtained was used for assay of total protein, ALT, AST and ALP. The liver tissues from the animals were surgically removed, blotted and weighed using a mettler p163 balance. One gramme was crushed in a mortar and then homogenized in cold $5 \mathrm{ml} 0.25 \mathrm{M}$ STKM buffer. This formed the whole liver homogenate (WLH).An aliquot of the WLH was used for WLH total protein estimation. The remainder of the WLH was centrifuged at $2000 \mathrm{~g}$ for 20 minutes in a refrigerated centrifuge. The supernatant was separated and immediately used for assay of AST, ALT and ALP activities. Liver tissue slices for histopathological examination were fixed in $10 \%$ formaldehyde preparatory to histological processing.

\section{Histological analysis}

The fixed liver tissues were sectioned into 5micron thickness and stained with Heamatoxilin and Eosin (H\&E) according to the method of Conn (1946).Photomicrographs (magnification: x400) were then developed.

\section{Biochemical Assay}

The total protein concentration in serum and WLH were estimated according to the Biuret method as modified by Donninger et al (1972) using bovine serum albumin as standard. Serum and liver activities of ALT, AST and ALP were estimated using laboratory kits obtained from Randox laboratory Ltd., United Kingdom and absorbance were read using a uv-vis spectrophotometer (DREL $300 \mathrm{HACH}$ ).

\section{Statistical Analysis}

Data are presented as mean \pm SD and analyzed for statistical significance among group means by one way analysis of variance (ANOVA) followed by a post-hoc least square difference (LSD) for individual group comparison with the help of a software SPSS 7.5 for windows. A P-value less than 0.05 were considered statistically significant.

\section{Results}

Table 1: Serum Level of total protein and activities of ALT, AST and ALP in experimental animals

\begin{tabular}{lllll}
\hline Parameter & $\begin{array}{c}\text { Total } \\
\text { protein } \\
(g / d l)\end{array}$ & $\begin{array}{c}A L T \\
I U / L)\end{array}$ & $\begin{array}{c}A S T \\
I U / L)\end{array}$ & $\begin{array}{c}A L P \\
(I U / L)\end{array}$ \\
Group & & & \\
\hline Group 1 & 5.80 & 21.75 & 25.71 & 107.55 \\
(Control) & \pm 0.29 & \pm 4.74 & \pm 8.66 & \pm 24.34 \\
Group 2 & 6.10 & 24.30 & 30.34 & 118.34 \\
& \pm 0.25 & \pm 6.58 & \pm 6.33 & \pm 21.30 \\
Group 3 & 5.97 & 21.90 & 29.58 & 109.86 \\
& \pm 0.38 & \pm 7.46 & \pm 10.4 & \pm 17.20 \\
Group 4 & 5.87 & 25.34 & 35.57 & 127.39 \\
& \pm 0.96 & \pm 5.99 & \pm 7.36 & \pm 25.28 \\
\hline
\end{tabular}

Results are presented as Mean \pm SD

Table 2: Whole liver homogenate protein and activities of ALT, AST and ALP of experimental animals

\begin{tabular}{lllll}
\hline Parameter & $\begin{array}{l}\text { WLH } \\
\text { Protein } \\
\text { (mg/g } \\
\text { Group }\end{array}$ & $\begin{array}{l}\text { WLHALT } \\
\text { (IUssue) } \\
\text { tissue })\end{array}$ & $\begin{array}{l}\text { WLHAST } \\
\text { (IU/mg } \\
\text { tissue) }\end{array}$ & $\begin{array}{l}\text { WLH } \\
\text { ALP } \\
(\text { IU/mg } \\
\text { tissue) }\end{array}$ \\
\hline Group & 145.04 & 77.62 & 117.34 & 3.76 \\
l(Control) & \pm 21.17 & \pm 9.28 & \pm 12.30 & \pm 0.41 \\
Group 2 & 147.30 & 77.50 & 129.62 & 3.69 \\
& \pm 19.25 & \pm 13.24 & \pm 14.36 & \pm 0.82 \\
Group 3 & 145.87 & 88.25 & 117.53 & 3.74 \\
& \pm 27.40 & \pm 14.73 & \pm 20.41 & \pm 0.63 \\
Group 4 & 152.74 & 86.08 & 124.25 & 3.81 \\
& \pm 24.33 & \pm 17.31 & \pm 19.67 & \pm 0.95 \\
\hline
\end{tabular}

Results are presented as Mean \pm SD

The serum level of total protein and activities of ALT, AST and ALP in experimental animals is shown on Table 1.0 .Total serum protein concentration in all the $A$. conyzoides treated groups were higher than control $(5.80 \pm 0.29 \mathrm{~g} / \mathrm{dl})$ with group 2 animals recording the highest level $(6.10 \pm 0.25 \mathrm{~g} / \mathrm{dl})$. However, none of the higher 
Ageratum conyzoides (goat weed) effect on serum protein and enzyme levels

levels were statistically significant $(\mathrm{p}>0.05)$. Similarly, serum activities of ALT, AST and ALP were all higher in the Ageratum conyzoides treated groups than in control animals although there were no significant increases in each of these parameters when compared to control values. The increases recorded for each parameter was also not dose dependent. The WLH protein level and activities of ALT, AST and ALP are also shown on Table 2. The WLH protein levels of all experimental groups were within the same range with the mean WLH protein level in the treated groups being slightly higher than controls. The same trend was observed for the WLH activities of ALT, AST and ALP in all experimental animals.

Histological examination of liver tissues of the respective experimental group of animals did not reveal any histopathological derangements as shown on plates I -IV. The plates were intensely stained with prominent central vein (V) from where the hepatocytes $(\mathrm{H})$ radiate outwards. The polygonal hepatocytes all showed distinct nuclei (N) and cell outline. The cytoplasm stained eosinophilic and hepatic sinusoids (S) run in between the hepatocytes.

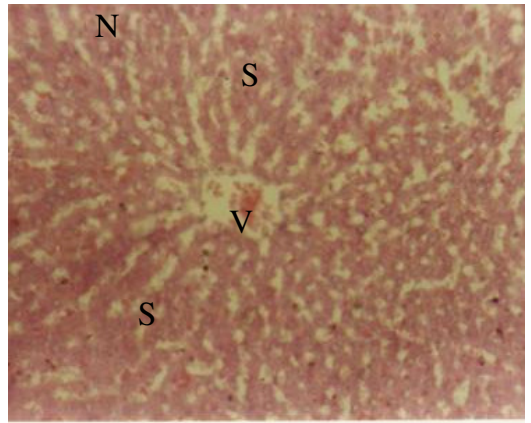

Plate I: Photomicrograph (x400) of control rat liver stained with $H$ and $E$

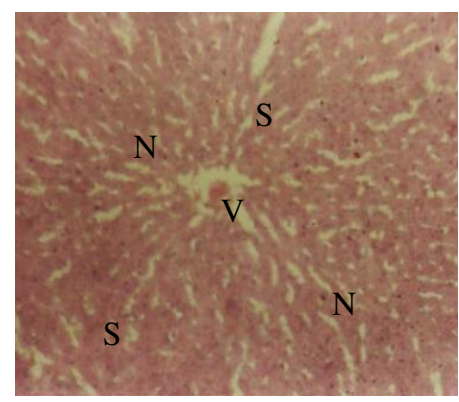

Plate II: Photomicrograph (x400) of rat liver treated with $200 \mathrm{mg} / \mathrm{kg}$ body weight of $A$. conyzoides stained with $H$ and $E$

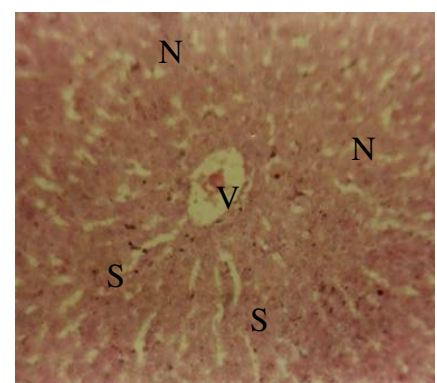

Plate III: Photomicrograph (x400) of rat liver treated with $400 \mathrm{mg} / \mathrm{kg}$ body weight of A. conyzoides stained with $H$ and $E$

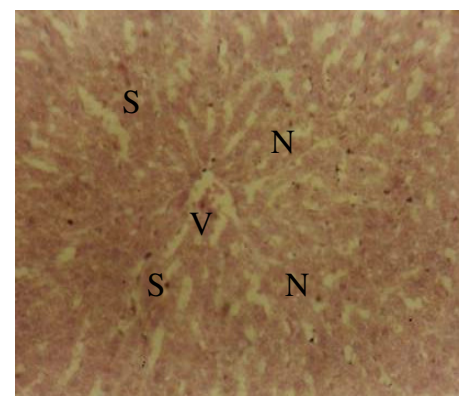

Plate IV: Photomicrograph (x400) of rat liver treated with $600 \mathrm{mg} / \mathrm{kg}$ body weight of A. conyzoides stained with $H$ and $E$.

\section{Discussion}

In many regions of the world medicinal plants contribute immensely in the healthcare of the population. Many of our rural population depend on a variety of plant materials for their wellbeing. These plants do not only supply essential nutrients but contain secondary metabolites which have proven efficacy against many diseases. In our local communities Ageratum conyzoides commonly referred to as "goat weed" is used for the treatment of fever, rheumatism, pneumonia, wounds, dysentery, etc. This study examined the impact of treatment of rats with varying doses of Ageratum conyzoides on serum and liver levels of total protein, AST, ALT and ALP activities, in an attempt to evaluate the hepatotoxic potential of this plant extract. The results obtained revealed that animals treated with test doses of the ethanolic leaf extract compared favorably with controls with respect to the toxicological indices estimated. Histopathological examination of liver tissues also did not reveal any degenerative changes in all treatment groups. This observation suggests that treatment of animals even at doses of $600 \mathrm{mg} / \mathrm{kg}$ body weight may not pose any toxic effect to the liver. Durodola (1977) had reported the use of this plant for its antibiotic, anti-inflammatory, 
analgesic, astringent and haemostatic activities. Ekundayo et al (1988) reported that the essential oil of the plant also possess significant antibiotic activity and is commonly used in treating local infections.

One of the organs usually affected by ingestion of xenobiotics is the liver. Generally, hepatic injury is often associated with alterations in the serum and liver levels of some enzymes notably ALT, AST and ALP (Whitby et al, 1984) and studies with medicinal plant extracts have shown the varying effects of photochemicals on serum and liver enzyme levels. While some phytochemicals are hepatotoxic,others are hepatoprotective. Akpanabiatu et al., (2003) in a study of the biochemical effect of Eleophorbia drupifera reported a decreased AST level in treated groups. Other workers have similarly reported changes in ALT, AST, ALP, GGT(gamma glutamyl transferase) activities in animals treated with plant extracts (Nada et al. 1997; Udosen and Ojong, 1998, Bumah et al, 2005 Akpanabiatu et al, 2005). The fact that total protein concentration as well as levels of ALT,AST and ALP in liver and serum of both control and treated groups were similar implies that Ageratum conyzoides may not pose any toxicological threat to the liver when used in traditional medicine at the doses investigated.

\section{References}

Achola, K. J., Muncenge, R. W. and Mwaura, A. M. (1994) Pharmacological properties of root and aerial extracts of Ageratum Conyzoides on isolated ileum and heart. Fitoterapia. 56: 103109.

Akpanabiatu, M. I., Igiri, A. O., Eyong, E. U. and Eteng, M. U. (2003). Biochemical and histological effects of Eleophorbia drupifera leaf extract in Wistar albino rats. Pharmaceut Biol. 41(2): 96-99.

Akpanabiatu, M.I. , Umoh, I.B., Eyong, E.U. and Udoh, F.V. (2005). Influence of Nauclea on rats fed on Coconut oil and non-coconut oil meals. Pharmaceut. Biol. 43 (2): 53-157.

Almagboul, A.Z., Farroq, A.A. and Tyagi, B.R. (1985). Antimicrobial activity of certain Sudanese plants used in folkloric medicine; screening for antibacterial activity, part II Fitoterapia, 56; 103-109.
Borthakur, N. and Barauh, A.K. (1987). Search for precocenes in Ageratum Conyzoides L. of North-East India. J. Indian Chem. Soc. 64: 540-581.

Bumah, V.V. Essien, E.U., Agbedahunsi, J.M. and Eka, O.U. (2005) Effect of Khaya grandifoliala (Melianceae) on some biochemical parameters in rats. $J$. Ethnopharmacol. 102(3): 446-449.

Donniger, C., Hatson, D.H. and Pickering, B.A. (1972) Phosphoric acid triesterglutathione akyl transferase. Mechanism of detoxification of dimethyl phosphate ester. Biochem. J. 126:701-702.

Durodola, J.J. (1977) Antibacterial property of crude extracts from herbal wound healing remedy - Ageratum Conyzoides Planta Med. 32:385-390.

Ekundayo, O., Sharma, O.S., Rao, E.V. (1988) Essential Oil of Ageratum Conyzoides. Planta Med. I54:55-57.

Ita, S.O. Ettarh, R.R. Antai, A.B., Akpagomeh, B. A. (2005) The Stimulatory effect of Intragastric administration of Ageratum conyzoides on gastric acid secretion in rats. Niger. J.Health Biomed. Sci. 4(2): 121-124..

Ita, S.O., Etim, O.E., Ben, E.E. and Ekpo, O.F. (2007) Haematopoietic properties of ethanolic leaf extract of Ageratum conyzoides in albino rats. Niger. J. Physiol. Sci. 22:(1-2) 83-87.

Kong, C.H. Hu, F., Hu, X. H., Liang, W.J. and Zhang, C.X (2004) Allelopathic plants. XV. Ageratum Conyzoides L. Allelopathy J. 14: 112.

Nada, S. A., Bashandy, S. A.E. and Negam, A. A. (1997). Evaluation of the hypoglycaemic activity of traditional herbal preparation in male diabetic rats. Fitoterapia, 68 (3): 240244.

Udosen, E.O. and Ojong, A.S. (1998). Hepatotoxic activity of Sacoglottis gabonensis in rats. Pharmaceut. Biol. 36(5): 368-371.

Whitby, L.G., Percy-Robb, I.W. and Smith, A. F. (1984). Enzymes test in diagnosis. In: Lecture notes on Clinical Chemistry, $3^{\text {rd }}$ ed. Blackwell Sci. Publication, London p 138-168.

Received: July 20, 2009

Accepted: August 14, 2009 